\title{
Deletion of the Mouse Homolog of KCNAB2, a Gene Linked to Monosomy 1p36, Results in Associative Memory Impairments and Amygdala Hyperexcitability
}

\author{
John J. Perkowski ${ }^{1}$ and Geoffrey G. Murphy ${ }^{1,2,3}$ \\ ${ }^{1}$ Neuroscience Graduate Program, ${ }^{2}$ Molecular \& Behavioral Neuroscience Institute, and ${ }^{3}$ Department of Molecular \& Integrative Physiology, University of \\ Michigan, Ann Arbor, Michigan 48109-0069
}

\begin{abstract}
Ablation of the distal end of the short arm of chromosome 1 [1p36 deletion syndrome (1p36DS)] is one of the most commonly occurring terminal deletion syndromes in humans, occurring in $\sim 1$ in 5000 newborns. Subjects with 1p36DS manifest a wide range of clinical features including growth delay, congenital heart defects, and craniofacial dysmorphism. In addition, individuals with 1p36DS often exhibit some form of neurological abnormality and are typically cognitively impaired. Although there is significant variability with regard to the extent of the deletion, several genes have been mapped to region $1 \mathrm{p} 36$ that are known to regulate neuronal function. One such gene-KCNAB2 - encodes the potassium channel auxiliary subunit $\mathrm{Kv} \beta 2$, which has been previously shown to modulate voltage-gated potassium currents in heterologous expression systems. Here, we present experiments characterizing mice in which the ortholog of $K C N A B 2$ was deleted. We find that deletion of Kcnab2 in mice leads to deficits in associative learning and memory. In addition, using whole-cell current-clamp, we find that deletion of Kcnab2 leads to a reduction in the slow afterhyperpolarization following a burst of action potentials and a concomitant increase in neuronal excitability in projection neurons in the lateral nucleus of the amygdala. Our results suggest that loss of $\mathrm{Kv} \beta 2$ likely contributes to the cognitive and neurological impairments observed in 1p36DS patients.
\end{abstract}

\section{Introduction}

Of all of the known chromosomal rearrangements, chromosome 1 p36 alterations are among the most common, occurring in 1 in 5000 births, with terminal deletion of $1 \mathrm{p} 36$ being the most common mutation (Gajecka et al., 2007). The deletion size in monosomy 1 p36 deletion syndrome (1p36DS) is quite variable, ranging from 1.5 to $>10.5 \mathrm{Mb}$ (Heilstedt et al., 2003). Given the variability in the deletion size, it is not surprising that the clinical features of individual cases can vary significantly (Kurosawa et al., 2005). One common clinical feature of 1p36DS is impaired cognition. The cognitive impairments are variable (Wu et al., 1999), ranging from moderate learning impairments with attention deficit disorder (D'Angelo et al., 2006) to severe mental retardation (Heilstedt et al., 2003; Kurosawa et al., 2005). Although the extent to which the short arm of chromosome 1 is damaged or deleted in 1p36DS is variable and the list of potential genes ablated is extensive, several candidate genes have been identified that may be responsible in part for various aspects of the syndrome. For example, the gene for matrix metalloproteinase

Received May 24, 2010; revised Sept. 22, 2010; accepted Oct. 7, 2010.

This work was funded by National Institute on Aging Grant T32-AG000114 (J.J.P.) and National Institute of Neurological Disorders and Stroke Grant R21NS059525 (G.G.M.). Special thanks to Dr. David Dolan and the Auditory Physiology Laboratory at The University of Michigan Hearing Research Core Center (National Institute on Deafness and Other Communication Disorders Grant P30DC005188). Additional thanks to Jennifer Meagher and Jason Gestwicki for their assistance with protein preparation and enzymatic assay.

Correspondence should be addressed to Dr. Geoffrey G. Murphy, University of Michigan, 5037 Biomedical Science Research Building, 109 Zina Pitcher Place, Ann Arbor, MI 48109-2200. E-mail: murphyg@umich.edu.

DOI:10.1523/JNEUROSCI.2634-10.2011

Copyright $\odot 2011$ the authors $\quad 0270-6474 / 11 / 310046-09 \$ 15.00 / 0$
23A/B $(M M P 23 A / B)$ has been identified as a candidate gene for cranial suture closure (Gajecka et al., 2007). Similarly, $K C N A B 2$, the gene that encodes the potassium channel auxiliary subunit $\mathrm{Kv} \beta 2$, has been advanced as a candidate gene responsible for the neurological phenotypes observed in patients with 1p36DS (Heilstedt et al., 2001).

Like other voltage-gated ion channels, potassium channel pore-forming subunits often associate with auxiliary subunits $(\beta$ subunits), which modify channel complex function (Torres et al., 2007). Previous studies have demonstrated that $\mathrm{Kv} \beta 2$ modulates inactivation rates of endogenously inactivating Kv1.4 currents (McCormack et al., 1995) and can act as a chaperone protein, promoting the trafficking of Kv1.1 and Kv1.2 to the membrane surface (Shi et al., 1996). Based on protein sequence homology, $\mathrm{Kv} \beta 2$ appears to be a member of the aldo-ketoreductase (AKR) superfamily (McCormack and McCormack, 1994). A recent report demonstrates that $\mathrm{Kv} \beta 2$ is in fact a functional $A K R$, which can use 4-cyanobenzaldehyde (4-CY) as a substrate for reduction to an alcohol (Weng et al., 2006). When applied to the intracellular side of an inside-out patch pulled from oocytes coexpressing $\mathrm{Kv} 1.4 \alpha$ subunits and $\mathrm{Kv} \beta 2,4-\mathrm{CY}$ decreased the rate of the $\mathrm{N}$-terminal inactivation of the channel complex (Weng et al., 2006). However, the role that $\mathrm{Kv} \beta 2$ plays in neuronal function in vivo remains unclear.

To determine the extent to which loss of $\mathrm{Kv} \beta 2$ might contribute to impairments in cognition and to gain a better understanding of its functional role in neuronal activity, we examined mice in which the ortholog of KCNAB2 was deleted. Homozygous deletion of Kcnab2 in mice leads to deficits in associative learning 
during pavlovian fear conditioning, which are independent of the AKR function of $K v \beta 2$. In addition, we find that deletion of Kcnab2 leads to alterations in the neurophysiology of projection neurons in the lateral nucleus of the amygdala including a reduction in the slow afterhyperpolarization (sAHP) following a train of action potentials and a concomitant increase in neuronal excitability.

\section{Materials and Methods}

\section{Mice}

$K_{c n a b 2^{-1-}}$ and $\mathrm{Kcnab2}^{\mathrm{Y} 90 \mathrm{~F}}$ point mutant mice have been previously described (McCormack et al., 2002). Both strains were maintained on a 129SvEv background by successively crossing offspring with $129 \mathrm{SvEv}$ wild-type mice purchased from Taconic Farms. Experiments were conducted with mice on a C57BL/6:129SvEv $\mathrm{F}_{2}$ hybrid background. Mice were housed in a room separate from all experimentation rooms and maintained on a 14/10 h light/dark cycle. Experiments were performed during the light cycle. Mice were between 2 and 6 months of age at the time of testing and approximately equal numbers of males and females were used. For all experiments, the experimenter was blind to the genotype of the mice. All experiments were conducted in accordance with the guidelines set forth by the University of Michigan Committee on Use and Care of Animals.

\section{Behavior}

Pavlovian fear conditioning. The basic methods for pavlovian fear conditioning have been previously described (McKinney et al., 2008b). For the experiments presented here, mice were trained within a single day or across multiple days.

In the single-day experiments, mice were trained in a single session and tested $24 \mathrm{~h}$ later. In some single-day experiments, the conditioned stimulus (CS) was the context in which the training occurred. Mice were placed in the conditioning chambers, and after $3 \mathrm{~min}$ a series of three unsignaled footshocks $(2 \mathrm{~s}, 0.5 \mathrm{~mA})$ were delivered via the stainless steel grid floor with an intershock interval of $1 \mathrm{~min}$. Conditioned fear to the context CS was assessed $24 \mathrm{~h}$ later by returning the mice to the same chambers and measuring freezing (defined as the cessation of all movement except that associated with respiration) for $5 \mathrm{~min}$. In other singleday experiments, the CS was a $30 \mathrm{~s}$ tone $(80 \mathrm{~dB}, 420 \mathrm{~Hz})$, which coterminated with a $2 \mathrm{~s}$ footshock $(0.5 \mathrm{~mA})$ delivered via the grid floor. For these experiments, mice were placed in the conditioning chambers, and after 3 min three tone-footshock pairings were delivered with an intershock interval of $1 \mathrm{~min}$. Conditioned fear to the tone CS was assessed $24 \mathrm{~h}$ later by returning the mice to a form of the conditioning chambers that had been reconfigured to a novel context by changing the smell and shape of the chambers as well as the lighting and background noise. After $2 \mathrm{~min}$ of baseline, freezing was measured in response to a $3 \mathrm{~min}$ tone.

In addition to the single-day training protocol, separate groups of mice were examined across multiple training days. We (McKinney and Murphy, 2006) and others (Brunzell et al., 2002; Sanders et al., 2005) have found that this type of training often reveals more subtle memory impairments and provides an acquisition curve that can be examined for performance deficits over time. In the multiday experiments, mice were given a single training trial each day in which a 3 min baseline was followed by a $30 \mathrm{~s}$ tone $(80 \mathrm{~dB}, 420 \mathrm{~Hz})$, which coterminated with a $2 \mathrm{~s}$ footshock $(0.5 \mathrm{~mA})$ delivered via the grid floor. Mice were removed from the chambers $30 \mathrm{~s}$ following the shock. In some experiments (see Fig. 1), conditioned fear to the context was assessed during training, and freezing to tone was $24 \mathrm{~h}$ after the last training session as described above. In other experiments (see Fig. 3), conditioned fear to the context was assessed during training as well as during a separate $5 \mathrm{~min}$ exposure to the context $24 \mathrm{~h}$ after the last training session. In these experiments, conditioned fear to the tone CS was assessed $24 \mathrm{~h}$ after the context test (i.e., $48 \mathrm{~h}$ after the last training trial) and was performed as described above. For all experiments, freezing was assessed using FreezeFrame software (Actimetrics). Freezing data are presented as the percentage freezing, which is the amount of time an individual animal spent freezing during a specified period of time divided by the duration of that period of time multiplied by 100 .
To determine shock threshold, one mouse at a time was transferred from its home cage and placed into a conditioning chamber. Multiple footshocks, $2 \mathrm{~s}$ in duration, were delivered beginning at a current intensity of $0.05 \mathrm{~mA}$ and increasing by $0.05 \mathrm{~mA}$ per shock. Shocks were separated by $15 \mathrm{~s}$ and delivered until the three behavioral criteria of flinch, vocalization, and jump were met. Flinch was defined as any sudden contraction or small, brief movement without any visible change in location within the chamber. Vocalization was defined as the utterance of sound. Jump was defined as a sudden large move with a visible change in location.

Asymptotic postshock freezing was determined in a single session for each mouse. Mice were transferred from their home cages to the conditioning chambers. After a 3 min baseline period, five footshocks $(0.5 \mathrm{~mA}$; $2 \mathrm{~s}$ ) were delivered, each followed by a $1 \mathrm{~min}$ postshock period during which the percentage time freezing was measured.

Open field and light/dark box. The open field and light/dark box experiments were performed as previously described (McKinney et al., 2008a,b). The open field chamber consisted of a white acrylic box with a square floor $71 \mathrm{~cm}$ per side with walls $30 \mathrm{~cm}$ tall. During analysis, the open field was divided into two zones, a peripheral and central zone. The peripheral zone was defined as the perimeter of the floor within $6.5 \mathrm{~cm}$ of the walls, and the central zone was defined as the remainder of the floor interior to the peripheral zone. Total distance traveled during the $5 \mathrm{~min}$ trial and the ratio of distance traveled in the central zone to the total distance traveled was calculated. The light/dark box was $46 \mathrm{~cm}$ long, 27 $\mathrm{cm}$ wide, and $30 \mathrm{~cm}$ tall. It was proportioned such that one third of its length comprised the dark enclosed compartment, made of black acrylic, and the remaining two thirds comprised the light compartment, made of white acrylic. Mice were placed in the light compartment and observed for $10 \mathrm{~min}$. The number of transitions made between the two compartments and the percentage of time spent in the light compartment were scored. For both experiments, position data were collected and analyzed using LimeLight software (Actimetrics).

Auditory brainstem response. Mice were anesthetized (ketamine $65 \mathrm{mg} /$ $\mathrm{kg}$, xylazine $3.5 \mathrm{mg} / \mathrm{kg}$, and acepromazine $2 \mathrm{mg} / \mathrm{kg}$ ). Body temperature was maintained through the use of water-circulating heating pads and heat lamps. Additional anesthetic (ketamine and xylazine) was administered if needed to maintain anesthesia depth sufficient to ensure immobilization and relaxation. Auditory brainstem responses (ABRs) were recorded in an electrically and acoustically shielded chamber (Acoustic Systems). Needle electrodes were placed at vertex (active) and the test ear (reference) and contralateral ear (ground) pinnae. Tucker Davis Technologies System II hardware and SigGen/BioSig software were used to present the stimulus and record responses. Tones were delivered through an EC1 (Tucker Davis Technologies), with the speculum placed just inside the tragus. Stimulus presentation was $15 \mathrm{~ms}$ tone bursts, with $1 \mathrm{~ms}$ rise/fall times, presented 10 per second. Up to 1024 responses were averaged for each stimulus level. Responses were collected for stimulus levels in $10 \mathrm{~dB}$ steps at higher stimulus levels, with additional $5 \mathrm{~dB}$ steps near the threshold. Thresholds were interpolated between the lowest stimulus level where a response was observed, and $5 \mathrm{~dB}$ lower, where no response was observed.

\section{Functional analysis of Kv $\beta 2$ Y90F mutation}

Molecular biology - construction of expression vector. Plasmids containing cDNA sequence coding for rat $\mathrm{Kv} \beta 2$ or rat $\mathrm{Kv} \beta 2: \mathrm{Y} 90 \mathrm{~F}$ were obtained from James Trimmer, University of California at Davis (Davis, CA) and cloned by the same methods in parallel. The fragments of DNA in each plasmid corresponding to residues 36-363 were amplified by PCR with overhanging primers to introduce SphI and BamHI restriction sites, respectively, at the $5^{\prime}$ and $3^{\prime}$ ends (forward primer: $5^{\prime}$-GGGGCATGCTCCAGTTTTACAGGAATCTGGGCAAA, reverse primer: 5'-GGGGGATCCCTTTTTGCTGTAGGGTTTATTGCCCAG). These fragments were then cloned into a pQE70 vector (Qiagen) between the SphI and BamHI sites to add a $6 \times$ histidine tag. Proper cloning was verified by DNA sequencing.

Protein expression and purification. XL-1 Blue bacterial cells were used to express protein. Cells were grown in Luria broth at $37^{\circ} \mathrm{C}$ until an $\mathrm{OD}_{600}$ of $\sim 0.8$, at which time the temperature was reduced to $20^{\circ} \mathrm{C}$. After 
20 min at an $\mathrm{OD}_{600}$ of $\sim 1.0$, expression was induced by adding isopropyl $\beta$-D-thiogalactopyranoside to a final concentration of $5 \mathrm{~mm}$. The cells were incubated at $20^{\circ} \mathrm{C}$ for an additional $16 \mathrm{~h}$ and then harvested by pelleting and freezing to $-80^{\circ} \mathrm{C}$. Throughout the purification procedure, the following buffer was used: $20 \mathrm{~mm}$ imidazole, $40 \mathrm{~mm}$ Tris $\mathrm{pH} 8.0,300$ mu KCl, $10 \%$ (v:v) glycerol, $1 \mathrm{~mm} \beta$-mercaptoethanol ( $\beta$-ME). The frozen cell pellet was resuspended in buffer, lysed by sonification, and spun to remove cellular debris. The clear cell lysate was added to TALON $\mathrm{Co}^{2+}$ resin (Clontech) and batch processed by incubating at $4^{\circ} \mathrm{C}$ with shaking for $1 \mathrm{~h}$. After four washes each with 10 bed volumes of buffer, the resin was transferred to a column. Protein was eluted from the column with buffer containing $300 \mathrm{~mm}$ imidazole and no $\beta$-ME. Protein concentration was determined using the absorption at $280 \mathrm{~nm}$ and extinction coefficient $1.596 / \mathrm{M} / \mathrm{cm}$.

Enzyme kinetics measurement. The oxidation of NADPH (single turnover hydride transfer) was used as measure of catalytic activity to determine reaction rate. $\mathrm{Kv} \beta 2$ or $\mathrm{Y} 90 \mathrm{~F}$ protein (at $3.6 \mathrm{mg} / \mathrm{ml}$ in elution buffer) was mixed with $5 \mathrm{~mm} 4$-carboxybenzaldehyde (4-CB; Sigma) in dimethyl sulfoxide (DMSO), and the absorption at $363 \mathrm{~nm}$ was measured once per minute for $90 \mathrm{~min}$ at $37^{\circ} \mathrm{C}$. This experiment was performed in triplicate with buffer-only controls. All data points were averaged for each condition.

\section{Electrophysiology}

Amygdala slice preparation. Mice were anesthetized with isoflurane and decapitated. Following removal of the cerebellum and brainstem, the rostral third of the remaining brain was removed. The exposed caudal surface was glued onto a cutting block, and the brain was covered with ice-cold $\left(<1^{\circ} \mathrm{C}\right)$ oxygenated sucrose-based cutting solution containing the following (in mM): $2.8 \mathrm{KCl}, 1 \mathrm{MgCl}_{2}, 2 \mathrm{MgSO}_{4}, 1.25 \mathrm{NaH}_{2} \mathrm{PO}_{4}, 1$ $\mathrm{CaCl}_{2}, 206$ sucrose, $26 \mathrm{NaHCO}_{3}, 10 \mathrm{D}$-glucose, and 0.40 ascorbic acid. Coronal slices $400 \mu \mathrm{m}$ thick were prepared with a vibratome. Sections containing the lateral amygdala were divided at the midline and transferred to a holding chamber filled with oxygenated artificial CSF (aCSF), which contained the following (in mM): $124 \mathrm{NaCl}, 2.8 \mathrm{KCl}, 2 \mathrm{MgSO}_{4}$, $1.25 \mathrm{NaH}_{2} \mathrm{PO}_{4}, 2 \mathrm{CaCl}_{2}, 26 \mathrm{NaHCO}_{3}, 10$ D-glucose, and 0.40 ascorbic acid. Slices rested at room temperature for at least $1 \mathrm{~h}$ before being individually transferred to a recording submersion chamber and continuously perfused $(\sim 1.5 \mathrm{ml} / \mathrm{min})$ with oxygenated aCSF heated to $31^{\circ} \mathrm{C}$.

Amygdala whole-cell recording. Whole-cell recordings were made from lateral nucleus of the amygdala (LA) projection neurons using a Dagan 3900A amplifier in bridge mode. Neurons were visualized with an Olympus BX51WI upright microscope equipped with infrared differential interference contrast optics. Patch pipettes made from Clark Borosilicate Standard Wall glass (Warner Instruments) and pulled using a P-97 Flaming-Brown pipette puller (Sutter Instruments) with resistances of 3-7 M $\Omega$ were used and filled with the following internal solution (in mM): 120 potassium methylsulfate, $20 \mathrm{KCl}, 10$ HEPES, $4 \mathrm{Na}_{2}$-ATP, 2 $\mathrm{MgCl}_{2}, 0.3$ GTP, 0.2 EGTA, and 7 phosphocreatine. Seal resistances of $>2 \mathrm{G} \Omega$ were achieved before rupturing into whole-cell mode. A neuron was considered to be a healthy projection neuron and acceptable for data collection if four conditions were met: (1) it had a resting membrane potential more hyperpolarized than $-58 \mathrm{mV}$; (2) it exhibited action potentials that overshoot $0 \mathrm{mV}$; (3) it exhibited spike accommodation to a sustained depolarizing current pulse; and (4) it exhibited a "sag" current in response to a strong hyperpolarizing current pulse (Washburn and Moises, 1992). Current steps of $5 \mathrm{~ms}$ were used to elicit a single action potential. Action potentials were measured from rest and were analyzed for spike threshold and amplitude. Spike broadening was determined by injecting a $100 \mathrm{~ms}$ current step sufficient to elicit five action potentials. Spike width was measured at one half of the action potential amplitude for each spike, from threshold to peak. Cells were held at resting membrane potential and the postburst AHP was studied using a $100 \mathrm{~ms}$ current step sufficient to elicit five action potentials. AHP measurements were made using the average of at least three successive traces from each neuron. Neuronal excitability was studied in these neurons using a series of current injections of increasing intensity ( $500 \mathrm{~ms}$ duration, -0.02 to $0.1 \mathrm{nA}, 0.01 \mathrm{nA}$ steps) while the neuron was at rest. All data were acquired and analyzed using pClamp 9.2. For analysis, sample sizes refer to the number of cells.

Statistics. All statistical analyses were completed using StatView version 5 (SAS Institute). All values are expressed as the mean \pm SEM. For group comparisons across a single measure, statistical analysis was performed using unpaired Student's $t$ tests. For comparisons across two or more measures or factors, a repeated-measures ANOVA was performed followed by planned post hoc comparisons using Fisher's protected least significant difference test. Multiple unplanned post hoc comparisons were made using a Bonferroni correction after achieving a significant omnibus test result in the repeated-measures ANOVA. The $\alpha$ level for all analyses was set to $5 \%$, and all $p$ values are reported as two tailed.

\section{Results}

\section{Deletion of Kcnab2 disrupts associative memory}

To determine to what extent deletion of Kcnab2 might impact associative learning, we examined the performance of Kcnab2 homozygous-null $\left(\mathrm{Kcnab2}^{-/-}\right)$mice and their wild-type $\left(\mathrm{Kcnab2}^{+/+}\right)$ littermates in pavlovian fear conditioning. The results from these experiments are presented in Figure 1. In the first experiment, the CS was the conditioning chambers in which the training took place. Kcnab2 $2^{+/+}$mice $(n=10)$ and $\mathrm{Kcnab}^{-/-}$mice $(n=8)$ were given three unsignaled footshocks ( $2 \mathrm{~s}$ shock with an intershock interval of $1 \mathrm{~min}$ ) during a single training trial. There was no significant difference in the amount of postshock freezing exhibited by Kcnab2 $2^{-1-}$ mice during training when compared with $\mathrm{Kcnab2}^{+/+}$littermates (Fig. $1 A$ ) (interaction for genotype $\times$ postshock periods 1-3: $\left.F_{(2,32)}=1.0, p=0.37\right)$. However, when exposed to the same context $24 \mathrm{~h}$ later, the $\mathrm{Kcnab2}^{-1-}$ mice froze significantly less than the Kcnab2 ${ }^{+/+}$(Fig. $\left.1 B\right)\left(t_{(1,16)}=2,76, p=\right.$ $0.014)$. In the second experiment, $\operatorname{Kcnab2}^{+/+}$mice $(n=16)$ and $\mathrm{Kcnab2}^{-/-}$mice $(n=11)$ were trained during a single training trial with three pairings of a $30 \mathrm{~s}$ tone with a $2 \mathrm{~s}$ footshock that coterminated with the tone. As before, both groups exhibited similar levels of postshock freezing during training (Fig. 1C) (genotype $\times$ postshock periods $1-3$ interaction: $F_{(2,50)}=0.74, p=$ $0.48)$. However, when re-exposed to the same tone used during training in a novel context the Kcnab2 $2^{-/-}$mice froze significantly less than the Kcnab2 ${ }^{+/+}$mice (Fig. 1D) (main effect of genotype: $\left.F_{(1,25)}=5.63, p=0.02\right)$. In fact, the level of conditioned fear in the Kcnab2 $2^{-1-}$ mice during the tone was not statistically different from baseline (pretone) freezing levels $\left(F_{(1,10)}=2.68, p=0.13\right.$ for main effect of tone). Finally, we examined associative learning in Kcnab2 $2^{+/+}$mice $(n=25)$ and Kcnab2 $2^{-/-}$mice $(n=19)$ using a multiday training protocol (Fig. $1 E, F)$. Mice were trained with a single tone-shock pairing each day, and freezing was assessed during the $3 \mathrm{~min}$ before the onset of the tone-shock pairing each day (Fig. 1E). Twenty-four hours later, mice were tested using tone as the CS in a novel context (Fig. $1 F$ ). Consistent with our previous findings $\mathrm{Kcnab2}^{-/-}$mice froze significantly less across training (Fig. 1E) (genotype $\times$ training interaction: $F_{(2,42)}=$ 5.65; $p=0.005$ ). Similarly, Kcnab2 $2^{-/}$mice froze significantly less on day 4 when exposed to the tone CS (Fig. $1 F$ ) (genotype $\times$ tone interaction $F_{(1,42)}=5.10 ; p=0.02$ ). These results demonstrate that the deletion of Kcnab2 leads to substantial impairments in associative learning as assessed by pavlovian fear conditioning. We also observed deficits in spatial learning in the Kcnab2 $2^{-/-}$mice (see supplemental Figs. 1, 2, available at www. jneurosci.org as supplemental material).

To ensure that deletion of Kcnab2 did not alter other functional domains that might result in a behavioral phenotype that could be misinterpreted as a deficit in associative learning, $\mathrm{KCnab2}^{+/+}$mice and Kcnab2 $2^{-/-}$mice were subjected to a battery of control experiments to assess shock reactivity, general anxiety- 
A

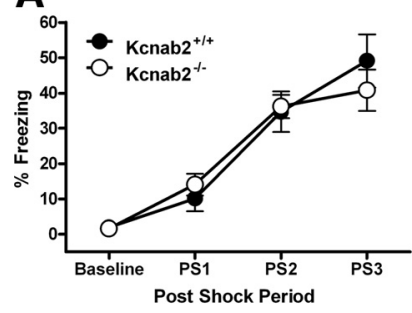

C

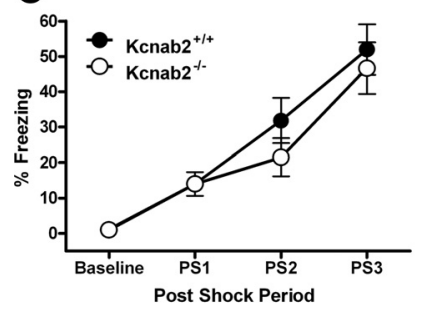

E

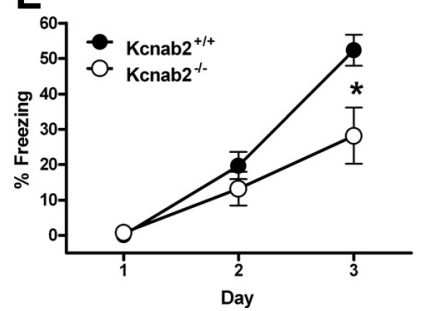

B

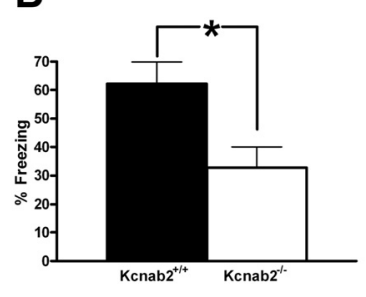

D

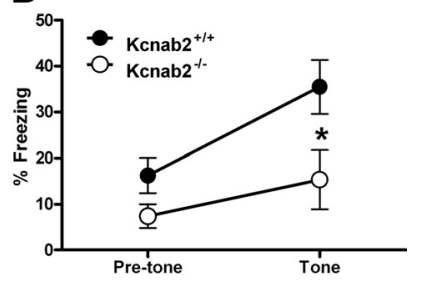

F

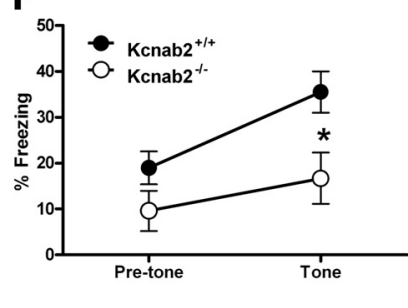

Figure 1. Deletion of $K c n a b 2$ disrupts associative learning. $\boldsymbol{A}, \boldsymbol{B}$, Pavlovian fear conditioning with context as the CS. A, Postshock freezing (measured for 1 min following shock) during training was similar for both Kcnab2 $2^{+/+}(n=10)$ and Kcnab2 $2^{-/-}(n=8)$ littermates. B, Both $K c n a b 2^{+/+}$and $K c n a b 2^{-/-}$mice exhibited a substantial increase over baseline freezing when re-exposed to the training context $24 \mathrm{~h}$ following training, but $K \mathrm{cnab2} 2^{-/-}$mice froze substantially less than wild-type mice. C, D, Pavlovian fear conditioning with a discrete tone as the CS. C, Repeated tone-shock pairings produced similar postshock freezing (measured for $30 \mathrm{~s}$ following shock) for both $K c n a b 2^{+/+}(n=16)$ and $K c n a b 2^{-/-}(n=11)$ littermates. D, Twenty-four hours after training, $K c n a b 2^{+/+}$and $K c n a b 2^{-/-}$mice were exposed to the tone $C S$ in a novel context. Kcnab2 $2^{-1-}$ mice froze significantly less than their $K c n a b 2^{+/+}$littermates. In fact, freezing in the $K c n a b 2^{-/-}$mice during tone presentation was not significantly different when compared with pretone levels of freezing $\left(F_{(1,10)}=2.68, p=0.13\right.$ for main effect of tone; one-way ANOVA). $\boldsymbol{E}, \boldsymbol{F}$, Similar results were obtained when both groups were trained across multiple days. $\boldsymbol{E}$, Naive $K c n a b 2^{+/+}(n=25)$ and $K c n a b 2^{-/-}(n=19)$ littermates were trained with a single tone-shock pairing each day. The percentage of freezing during the $3 \mathrm{~min}$ period before the tone-shock pairing for each day is presented. As before, the $K c n a b 2^{-1-}$ mice froze substantially less than wild-type mice. $\boldsymbol{F}$, Twenty-four hours after the final training trial, both groups were placed in a novel context and freezing to the tone CS was measured. Both $K c n a b 2^{+/+}$and $K c n a b 2^{-/-}$mice exhibited substantial increase over baseline freezing when re-exposed to the tone. However $K c n a b 2^{-1-}$ mice froze substantially less than wild-type mice. In all graphs, data are presented as mean \pm SEM. ${ }^{*} p<0.05$ for planned post hoc comparisons $(\boldsymbol{D}-\boldsymbol{F})$ and unpaired $t$ test $(\boldsymbol{B})$.

like behavior, and auditory processing. To assess shock sensitivity, naive mice were placed in the conditioning chamber and given footshocks of gradually increasing current intensity. The values of current were recorded for the level at which the mice showed outward signs of perceiving shock. The data presented in Figure $2 \mathrm{~A}$ demonstrate that there was no significant difference between $\mathrm{Kcnab2}^{+/+}$mice $(n=10)$ and $\mathrm{Kcnab}^{-/-}$mice $(n=7)$ in the current levels at which the mice began to flinch $\left(t_{(1,12)}=\right.$ $0.83, p=0.42)$, vocalize $\left(t_{(1,15)}=0.37, p=0.72\right)$, or jump $\left(t_{(1,15)}=0.67, p=0.51\right)$. In addition, maximal freezing levels were assessed in naive Kcnab2 $2^{+/+}$mice $(n=8)$ and $\mathrm{Kcnab2}^{-/-}$ mice $(n=5)$. After a 3 min baseline period, mice were given a series of five unsignaled footshocks ( 1 min intershock interval)

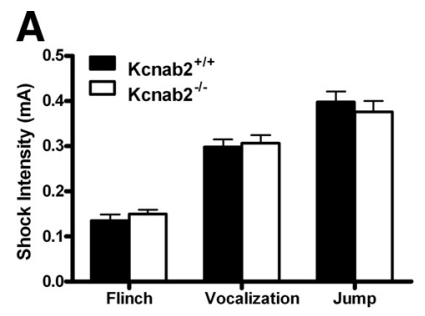

B
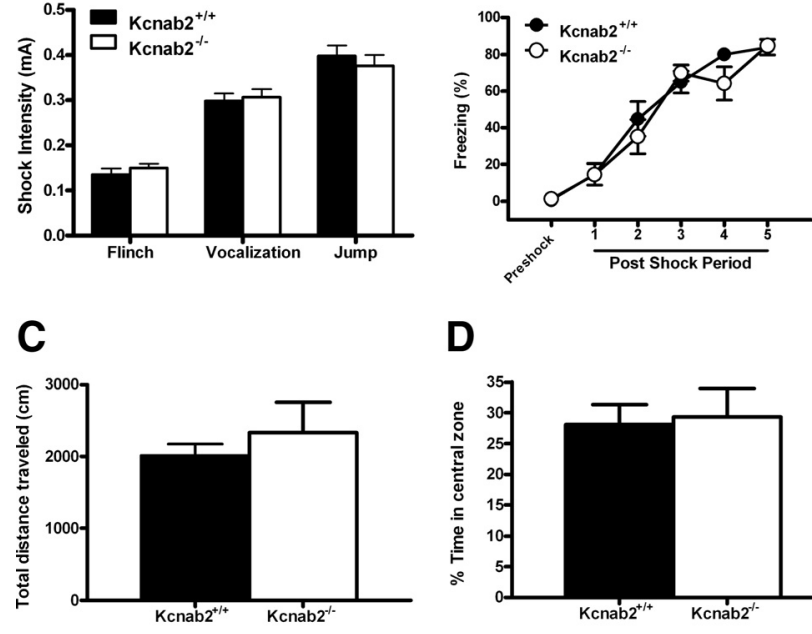

D
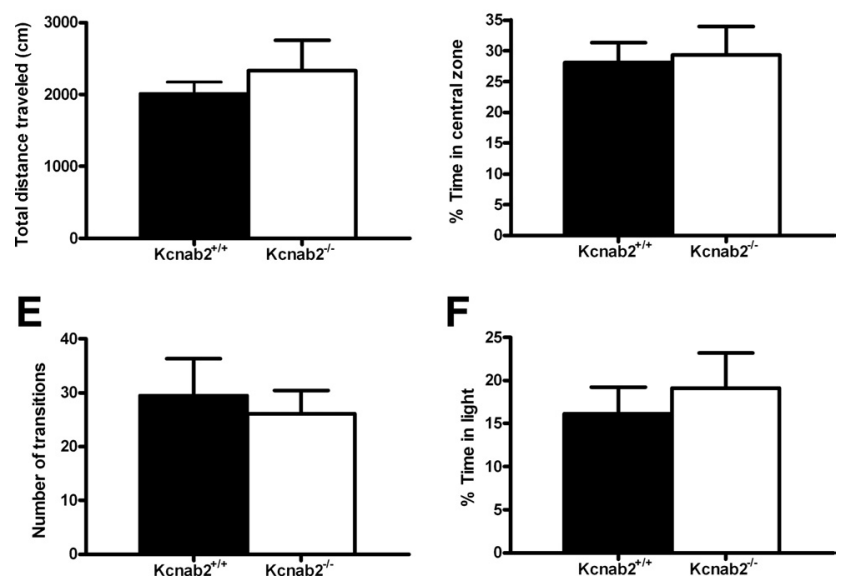

F

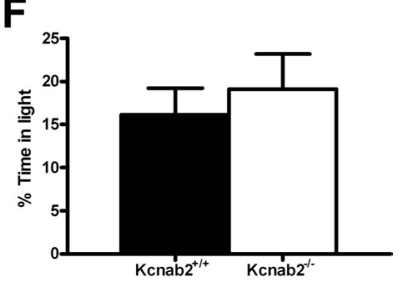

Figure 2. Deletion of Kcnab2 does not alter shock reactivity, mobility, or anxiety-like behavior. $\boldsymbol{A}$, Shock reactivity was assessed in $K c n a b 2^{+/+}$mice $(n=10)$ and $K c n a b 2^{-/-}$mice $(n=$ 7). There was no significant difference in the current levels at which the mice began to flinch, vocalize, or jump. $\boldsymbol{B}$, Maximal freezing levels were assessed in naive $K c n a b 2^{+/+}$mice $(n=8)$ and $K c n a b 2^{-1-}$ mice $(n=5)$. After a 3 min baseline period, mice were given a series of five unsignaled footshocks (1 min intershock interval) and postshock freezing was measured. $C, D$, Performance in the open field was not significantly different in $K c n a b 2^{-1-}$ mice $(n=10)$ compared with $K c n a b 2^{+/+}$mice $(n=11)$ when the total distance traveled was measured $(\boldsymbol{C})$ or when the percentage of time in the center zone was quantified $(\boldsymbol{D}) . \boldsymbol{E}, \boldsymbol{F}$, Similar results were obtained in the light/dark box. The total number of transitions between compartments was not significantly different in the $K c n a b 2^{-/-}$mice compared with $K c n a b 2^{+/+}$mice nor was there a significant difference in the percentage of time that the $\mathrm{Kcnab2}^{-/-}$mice spent in the brightly lit compartment of the light/dark box. In all graphs, data are presented as mean \pm SEM.

and postshock freezing was measured (Fig. $2 B$ ). Both groups exhibited robust postshock freezing, which reached asymptotic levels ( $>80 \%$ freezing) after five footshocks. There was no significant difference in postshock freezing levels when evaluated by two-way $\operatorname{ANOVA}\left(F_{(4,11)}=1.29, p=0.29\right.$ for genotype $\times$ postshock interaction). Collectively, the data presented in Figure $2 A, B$ demonstrate that deletion of Kcnab2 does not alter shock reactivity. General anxiety-like behavior was assessed in the open field (Fig. 2C,D) and light/dark box (Fig. $2 E, F$ ). Kcnab2 $2^{+/+}$mice $(n=11)$ and Kcnab2 $2^{-1-}$ mice $(n=10)$ exhibited similar levels of mobility in the open field as measured by the total distance traveled (Fig. $2 C)\left(t_{(1,19)}=0.72, p=0.48\right)$ and spent approximately equivalent amounts of time in the center zone of the open field (Fig. $2 D)\left(t_{(1,19)}=0.21, p=0.83\right)$. In the light/dark box, both groups of mice made approximately the same number of transitions between the light and dark compartments (Fig. 2E) $\left(t_{(1,19)}=0.43, p=0.67\right)$, suggesting that general mobility was not impacted by deletion of Kcnab2. Kcnab2 $2^{-1-}$ mice were equally averse to the brightly lit compartment, spending an equivalently small amount of time in the light as the Kcnab2 ${ }^{+/+}$mice (Fig. $2 \mathrm{~F}$ ) $\left(t_{(1,19)}=0.57, p=0.57\right)$. In addition, auditory processing was not altered in the Kcnab2 $2^{+/+}$mice, as measured by auditory brainstem response (Table 1 ). The ABR represents the synchronized 


\begin{tabular}{lllcl}
\multicolumn{5}{l}{ Table 1. Auditory brainstem response thresholds for $\mathrm{Kcnab2}^{+/+}$and $\mathrm{Knab2}^{-/-}$mice } \\
\hline & $n$ & $4 \mathrm{kHz}$ & $12 \mathrm{kHz}$ & $24 \mathrm{kHz}$ \\
\cline { 3 - 5 } & 4 & $26.3 \pm 8.1$ & $9.3 \pm 2.2$ & $14.5 \pm 4.3$ \\
$\mathrm{Kcnab2}^{-/-}$ & 4 & $33.5 \pm 3.1$ & $22.3 \pm 6.40$ & $41.0 \pm 20.0$ \\
$K_{\mathrm{nnab2}}{ }^{+/+}$ & 4 &
\end{tabular}

$\mathrm{dB} S P L$, Sound pressure level in decibels. Values are given as mean \pm SEM.
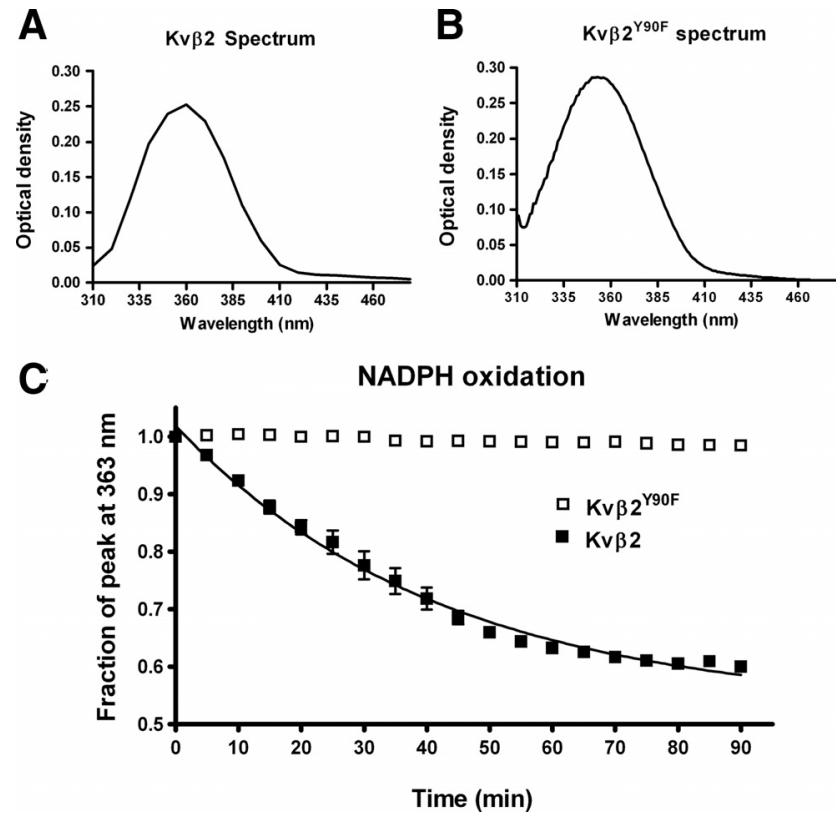

Figure 3. The Y90F point mutation abolishes catalytic activity of $\operatorname{Kv} \beta 2$. $A, B$, Purified wildtype $K v \beta 2$ protein $(\boldsymbol{A})$ and mutated $K v \beta 2: Y 90 F$ protein $(\boldsymbol{B})$ both show a peak absorption spectrum at $363 \mathrm{~nm}$, indicating that NADPH is naturally bound following purification and that the Y90F mutation does not prevent NADPH binding. $C$, After addition of exogenous substrate, 4-carboxyaldehyde, the absorption peak at $363 \mathrm{~nm}$ decreases exponentially for wild-type Kv $\beta 2$ but shows no appreciable change for mutant $\mathrm{Kv} \beta 2: \mathrm{Y} 90 \mathrm{~F}$, indicating that the Y90F mutant abolishes the catalytic activity of $\mathrm{Kv} \beta 2$. Data are presented as mean \pm SEM.

activity of the auditory nerve and brainstem in response to an auditory tone stimulus presented to an anesthetized mouse (Boettcher, 2002). The responses are measured with EEG electrodes and appear as a series of waveforms. The temporal position of these waveforms generally corresponds to neural activity generation in a spatially specific manner such that the first waveforms are generated in the peripheral portion of the auditory nerve and later waveforms are generated by progressively more and more central anatomical locations (i.e., central portions of the auditory nerve, cochlear nucleus, superior olivary complex). The ABR thresholds (measured as sound pressure level in decibels) of tone stimuli at 4,12 , and $24 \mathrm{kHz}$ were individually determined in $\mathrm{Kcnab2}^{+/+}$and $\mathrm{Kcnab2}^{-/-}$mice by reducing the intensity of the tone stimuli until an ABR was no longer detectable (Table 1). Repeated-measures ANOVA revealed no significant main effect of genotype $\left(F_{(1,6)}=2.251, p>0.05\right)$, effect of frequency $\left(F_{(2,12)}=2.141, p>0.05\right)$, or interaction of genotype and frequency $\left(F_{(2,12)}=0.901, p>0.05\right)$ between Kcnab2 $^{+/+}$and $\mathrm{Kcnab2}^{-/-}$mice in ABR thresholds across the frequencies tested. These findings demonstrate that the neural auditory sensitivity to acoustic stimuli is functionally intact in $\mathrm{Kcnab2}^{-/-}$mice. Taken collectively, these results demonstrate that $\mathrm{Kcnab}^{-/-}$mice exhibit normal locomotor activity, respond normally to anxietyproducing stimuli and exhibit intact processing of auditory stimulation.
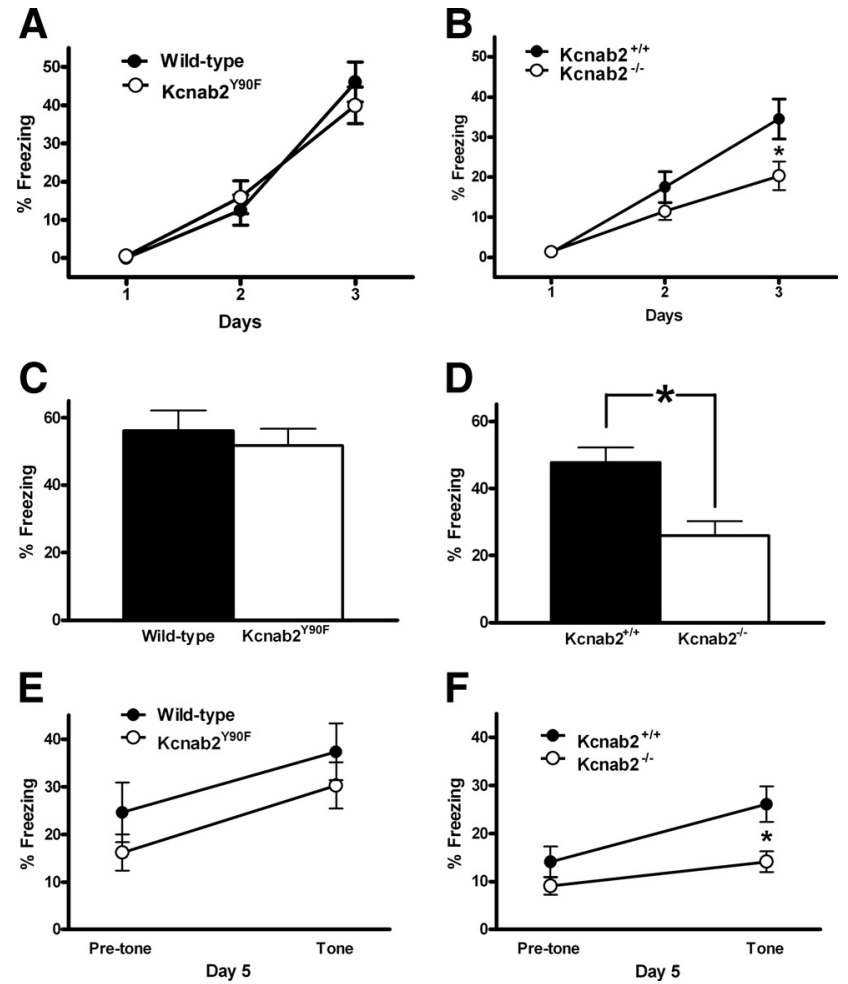

Figure 4. Disruption of AKR function does not lead to impairments in pavlovian fear conditioning. Mice were trained using a multiday training protocol in which a single tone-shock pairing was delivered after a 3 min baseline each day for 3 consecutive days (Fig. $3 A, B$ ). 0 n the following day, day 4, mice were returned to the training chamber for $5 \mathrm{~min}$ and freezing levels were measured in the absence of tone (Fig. 3C,D). Twenty-four hours later, on day 5 , mice were placed in a novel chamber and after 2 min mice were exposed to the same tone that was used during training for $3 \mathrm{~min}$ (Fig. $3 E, F)$. Data for the AKR point mutant $\left(K c n a b 2^{Y 90 F}\right)$ mice $(n=16)$ and their wild-type littermates $(n=16)$ are presented in the left panels $(\boldsymbol{A}, \boldsymbol{C}, \boldsymbol{E})$. $\boldsymbol{A}$, During training, wild-type and $K \mathrm{Cnab} 2^{Y 9 O F}$ mice exhibited increased levels of freezing as training progressed; however, there was no significant difference in their performance. $C$, When re-exposed to the conditioning chambers, wild-type and $K c n a b 2^{Y 90 F}$ mice exhibited similar amounts of freezing. $\boldsymbol{E}$, When tested for conditioning to the tone, wild-type and $K c n a b 2^{Y 90 F}$ mice responded with increased levels of freezing but did not significantly differ from one another. These results are in marked contrast to the results from the same experiments using $K \mathrm{cnab2} 2^{-/-}$mice ( $n=$ $24)$ and $K c n a b 2^{+/+}$mice $(n=34)$, which are presented in the right panels $(\boldsymbol{B}, \boldsymbol{D}, \boldsymbol{F})$. Consistent with our previous experiments, $K c n a b 2^{-/-}$mice exhibited significant impairments during training $(\boldsymbol{B})$ and when tested for context recall $(\boldsymbol{D})$ or when presented with the tone $\mathrm{CS}$ used during training $(\boldsymbol{F})$. In all graphs, data are presented as mean \pm SEM. ${ }^{*} p<0.05$ for planned post hoc comparisons $(\boldsymbol{B}, \boldsymbol{E}, \boldsymbol{F})$ and unpaired $t$ test $(\boldsymbol{D})$.

\section{Disruption of AKR function does not alter associative learning}

To determine whether the associative learning deficits that we observed in the Kcnab2 $2^{-/-}$mice were due to a loss of the $\mathrm{Kv} \beta 2$ protein itself or specifically due to a loss of the AKR function of the $K v \beta 2$ protein encoded by Kcnab2, we performed a series of experiments using mice in which a single amino acid substitution was made (tyrosine to phenylalanine) at position 90 (McCormack et al., 2002). To confirm that the Y90F point mutation did in fact abolish AKR function, we performed standard enzyme kinetics measurements using the oxidation of NADPH as a measure of catalytic activity to compare reaction rates of wild-type $\mathrm{Kv} \beta 2$ and $\mathrm{Kv} \beta 2^{\mathrm{Y} 90 \mathrm{~F}}$ proteins. Data from these experiments are presented in Figure 3. The tyrosine-to-phenylalanine substitution completely abolished the AKR activity of $\mathrm{Kv} \beta 2$. These results confirm previous experiments demonstrating that the tyrosine at position 90 plays a critical role in the AKR function of $\mathrm{Kv} \beta 2$ (Tipparaju et al., 2008). 
Table 2. Basic membrane properties of projection neurons in the lateral amygdala

\begin{tabular}{llllcr}
\hline & $n$ & Resting membrane potential $(\mathrm{mV})$ & Input resistance $(\mathrm{M} \Omega)$ & Spike threshold $(\mathrm{mV})$ & Spike threshold $(\mathrm{nA})$ \\
\hline Kcnab2 $^{-/-}$ & 19 & $-70.2 \pm 1.5$ & $145.2 \pm 14.1$ & $52.2 \pm 1.54$ & Spike height $(\mathrm{mV})$ \\
Kcnab2 $^{+/+}$ & 24 & $-70.8 \pm 1.0$ & $129.0 \pm 15.9$ & $51.9 \pm 0.53 \pm 0.07$ & $97.6 \pm 2.6$ \\
\hline
\end{tabular}

Values are given as mean \pm SEM.

To determine whether loss of AKR function was sufficient to disrupt associative memory formation, $K c n a b 2^{Y 90 F}$ point mutant mice $(n=16)$ and wild-type littermates $(n=16)$ were trained using a multiday training protocol in which mice were given a single tone-shock pairing every day for $3 \mathrm{~d}$ (Fig. 4). During training, the Kcnab2 $2^{Y 9 O F}$ and wild-type mice exhibited similar levels of freezing measured during the $3 \mathrm{~min}$ that preceded the tone-shock pairings on days 1 through 3 (Fig. 4A) (interaction for genotype $\times$ postshock periods $\left.1-3: F_{(2,60)}=1.2, p=0.31\right)$. Twentyfour hours later, the mice were returned to the training chamber and freezing was measured for $5 \mathrm{~min}$ in the absence of tone (Fig. $4 C)$. The Kcnab2 ${ }^{Y 9 O F}$ mice exhibited levels of freezing that were comparable to their wild-type littermates $\left(t_{(1,16)}=0.57, p=\right.$ $0.58)$. Twenty-four hours later, both groups of mice were placed in a novel context and freezing levels were measured during the presentation of the same tone used during training (Fig. $4 E$ ). Both groups exhibited increased levels of freezing during the presentation of the tone $\left(F_{(1,30)}=19.3, p=0.0001\right.$ for effect of tone), but there was not a statistical difference between $K c n a b 2^{Y 90 F}$ and wild-type mice (genotype $\times$ tone interaction: $F_{(1,30)}=0.04, p=$ $0.84)$. In contrast, $\mathrm{Kcnab}^{-/-}$mice $(n=24)$ exhibited substantial impairments when compared with $\mathrm{Kcnab2}^{+/+}$mice $(n=34)$ during the training (Fig. $4 B$ ) (genotype $\times$ training interaction: $\left.F_{(2,56)}=3.91, p=0.02\right)$, the context test (Fig. $\left.4 D\right)\left(t_{(1,56)}=3.44\right.$, $p=0.001$ ), as well as during tone presentation (Fig. $4 F$ ) (genotype $\times$ tone interaction: $\left.F_{(2,56)}=7.33, p=0.009\right)$. These results demonstrate that the deficits in associative learning that result from deletion of Kcnab2 are not due to the loss of the AKR function of $\operatorname{Kv} \beta 2$.

\section{Deletion of Kcnab2 leads to aberrant amygdala function}

Deletion of Kcnab2 resulted in impairments in pavlovian fear conditioning when the CS used was either a discrete stimulus (tone) or training context, suggesting that loss of Kcnab2 may have disrupted neuronal function within the amygdala. To examine the impact of Kcnab2 deletion on neuronal function, wholecell recordings were made from projection neurons in the LA. For these experiments, recordings were made from a total of 15 $\mathrm{Kcnab2}^{-/-}$mice (19 neurons) and $16 \mathrm{Kcnab2}^{+/+}$mice (24 neurons). Deletion of Kcnab2 did not significantly alter the resting membrane potential (Table 2$)\left(t_{(1,41)}=0.40, p=0.69\right)$ or input resistance (Table 2) $\left(t_{(1,41)}=0.74, p=0.46\right)$. In addition, there was no difference in spike height (Table 2) $\left(t_{(1,41)}=1.7, p=\right.$ $0.09)$, action potential threshold (Table 2) $\left(t_{(1,41)}=0.19, p=\right.$ $0.85)$, or the current required to elicit a single action potential (Table 2) $\left(t_{(1,41)}=0.85, p=0.40\right)$ in the Kcnab2 $2^{-/-}$mice when compared with $\mathrm{Kcnab2}^{+/+}$littermates. These results demonstrate that deletion of Kcnab2 does not significantly alter basic neuronal properties in the lateral amygdala.

It has previously been demonstrated that deletion of Kcnabl, the gene that encodes the potassium channel auxiliary subunit $\mathrm{Kv} \beta 1.1$, results in decreases in the postburst AHP and activitydependent spike broadening, and increases neuronal excitability in the hippocampus (Giese et al., 1998; Murphy et al., 2004). Similar to these previous results, we found that deletion of Kcnab2 leads to significant reductions in the postburst AHP of
$A_{1}$

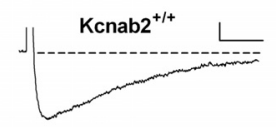

$A_{2}$

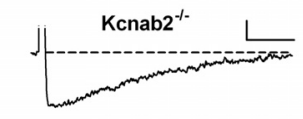

B

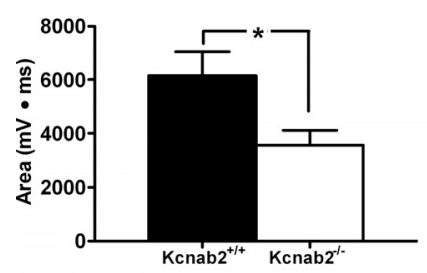

C

D

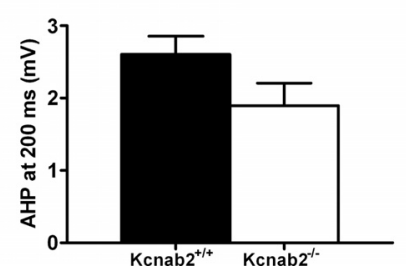

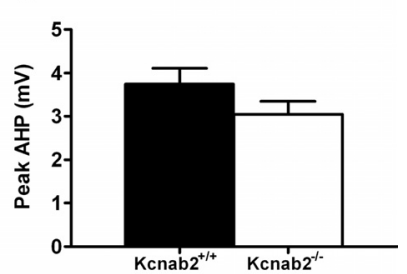

E

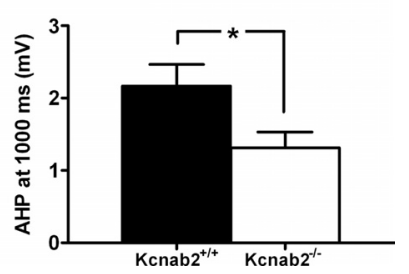

Figure 5. Deletion of $K c n a b 2$ significantly reduces the postburst AHP. $\boldsymbol{A}_{1}, \boldsymbol{A}_{2}$, Representative traces from recordings made in the lateral amygdala from $K \mathrm{cnab2} 2^{+/+}\left(\boldsymbol{A}_{\mathbf{1}}\right)$ and $K \mathrm{cnab2} 2^{-/-}$ mice $\left(\boldsymbol{A}_{\mathbf{2}}\right)$ are presented. Action potentials have been truncated to expand the AHP. Calibration: $1 \mathrm{mV} / 1 \mathrm{~s}$. $\boldsymbol{B}$, There was a significant reduction in the overall area of the AHP in $K c n a b 2^{-/-}$mice. C, Deletion of Kcnab2 did not significantly reduce the peak postburst AHP. D, Although there was a trend to significance ( $p=0.08$ ), there was no significant difference in the AHP amplitude measured at 200 ms after the end of the current pulse. $\boldsymbol{E}$, Deletion of Kcnab2 significantly reduced the later component of the postburst AHP. There was a significant reduction in the AHP in projection neurons in the amygdala of $K c n a b 2^{-1-}$ mice when measured at $1000 \mathrm{~ms}$ after the end of the current step. Data are presented as mean \pm SEM. ${ }^{*} p<0.05$ for unpaired $t$ test.

projection neurons within the LA (Fig. 5). For these experiments, neurons were depolarized from rest with a 100 ms suprathreshold current pulse of sufficient amplitude to elicit five action potentials that reliably produced a sizable postburst AHP. Although the amount of current required to elicit five action potentials was not significantly different for Kcnab2 $2^{-/-}$mice when compared with Kcnab2 ${ }^{+/+}$littermates $\left(0.46\right.$ vs $0.54 \mathrm{nA}$, respectively; $t_{(1,37)}=$ $1.69, p=0.10)$, the resulting postburst AHP observed in the $\mathrm{Kcnab2}^{-/-}$mice was significantly smaller (Fig. $5 A_{1}, A_{2}$ ). This reduction in the Kcnab2 $2^{-/}$mice was reflected in the group data when the area of the postburst AHP was measured. The postburst AHP area was significantly smaller in $\mathrm{Kcnab2}^{-/-}$mice when compared with Kcnab2 $2^{+/+}$littermates (Fig. $\left.5 B\right)\left(t_{(1,37)}=2.29\right.$, $p=0.03$ ). Deletion of Kcnab2 did not appear to alter the early components of the postburst AHP. Neither the peak amplitude of the AHP (Fig. $5 C)\left(t_{(1,37)}=1.42, p=0.16\right)$ nor the amplitude at $200 \mathrm{~ms}$ (Fig. $5 D)\left(t_{(1,37)}=1.80, p=0.08\right)$ was significantly different in neurons from Kcnab2 $2^{-/-}$mice when compared with $K c n a b 2^{+/+}$littermates, although there was a trend toward significance for the amplitude at $200 \mathrm{~ms}$. Instead, it appears that deletion of Kcnab2 selectively reduces the later, or slow, AHP. There was a significant reduction in the AHP measured at $1000 \mathrm{~ms}$ after 


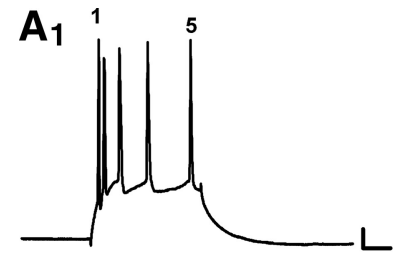

$\mathrm{Kcnab2}^{+/+}$

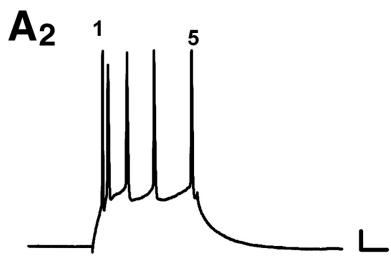

$\mathrm{Kcnab2}^{-1-}$

$B_{1}$

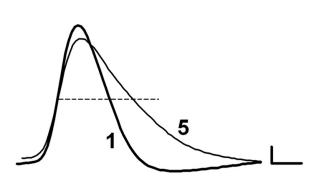

$B_{2}$

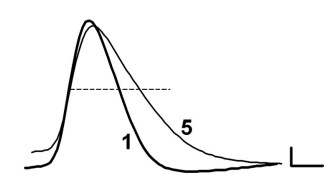

$\mathrm{Kcnab2}^{+/+}$

$\mathrm{Kcnab2}^{-/-}$

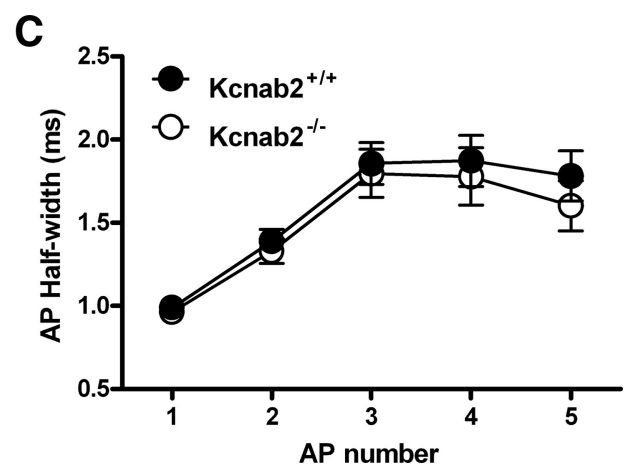

Figure 6. Deletion of $K c n a b 2$ does not decrease activity-dependent spike broadening. $A_{1}$ $A_{2}$, Neurons from $K c n a b 2^{+/+}\left(A_{1}\right)$ and $K c n a b 2^{-/-}\left(A_{2}\right)$ mice were depolarized sufficiently to elicit five action potentials (APs). Calibration: $10 \mathrm{mV} / 25 \mathrm{~ms}$. $\boldsymbol{B}_{1}, \boldsymbol{B}_{2}$, Representative traces for spikes 1 and 5 from the bursts in $A_{\boldsymbol{1}}$ and $\boldsymbol{A}_{\boldsymbol{2}}$, respectively, are presented. Spike width was measured at half-maximal spike amplitude (indicated by the dashed line). Calibration: $10 \mathrm{mV} /$ $0.5 \mathrm{~ms}$. C, Group data for spikes 1 through 5 . There was no significant difference in spike broadening between the two groups. Data are presented as mean \pm SEM.

the current pulse offset in Kcnab2 $2^{-/-}$mice when compared with Kcnab2 $^{+/+}$littermates (Fig. $\left.5 E\right)\left(t_{(1,37)}=2.21, p=0.03\right)$.

Mathematical simulations have led to the suggestion that deletion of Kcnab1 leads to a reduction in the sAHP by reducing activity-dependent spike broadening, which in turn reduces the amount of postburst calcium influx that activates the calciumactivated potassium channels that gate the sAHP (Murphy et al., 2004). To determine whether deletion of Kcnab2 might similarly reduce activity-dependent spike broadening in the LA, projection neurons were depolarized from rest with a $100 \mathrm{~ms}$ current pulse sufficient to elicit five action potentials (Fig. $6 A_{1}, A_{2}$ ), and the spike width was measured at one half the maximal spike height (Fig. $6 B_{1}, B_{2}$ ). Group data from these experiments are presented in Figure 6C. Neurons from Kcnab2 $2^{+/+}$and Kcnab2 $2^{-/-}$mice both exhibited activity-dependent spike broadening $\left(F_{(4,30)}=\right.$ $64.5, p=0.0001$ for broadening), but there was no significant difference in the amount of broadening between the two groups (genotype $\times$ broadening interaction: $F_{(4,30)}=0.42, p=0.80$ ). These results suggest that the decreased sAHP observed in the $\mathrm{KCnab2}^{-/-}$mice is not related to spike broadening.

In the hippocampus as well as the amygdala, alterations in the AHP can impact neuronal excitability (Faber and Sah, 2003b). To determine whether the reduced AHP observed in the Kcnab2 $2^{-/-}$ mice might alter neuronal excitability, lateral amygdala projection neurons in $\mathrm{Kcnab2}^{+/+}$and Kcnab2 $2^{-/-}$mice were depolarized with prolonged (500 ms) perithreshold current steps (Fig. 7).

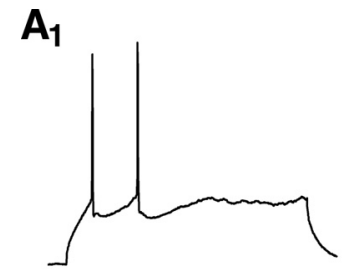

$\mathrm{Kcnab2}^{+/+}$
$A_{2}$

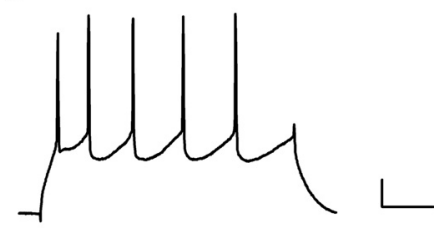

$\mathrm{Kcnab2}^{-/-}$
B

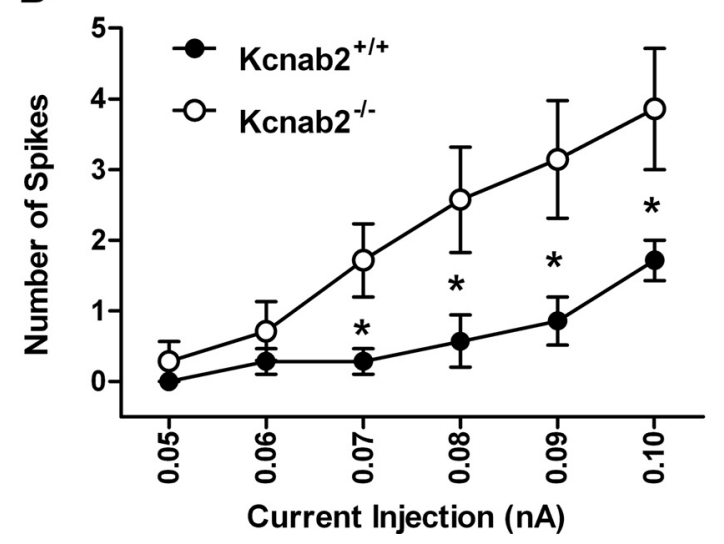

Figure 7. Deletion of $K c n a b 2$ leads to aberrant excitability of projection neurons in the lateral amygdala. $A_{1}, A_{2}$, Representative recordings of repetitive spiking of neurons in the lateral amygdala from $K c n a b 2^{+/+}\left(A_{1}\right)$ and $K c n a b 2^{-/-}$mice $\left(A_{2}\right)$ in response to a $500 \mathrm{~ms}$ long, 0.10 $n$ A current step. Calibration: $10 \mathrm{mV} / 100 \mathrm{~ms}$. $\boldsymbol{B}$, Group data are plotted as the average number of spikes elicited at each current step. Data are presented as mean \pm SEM. ${ }^{*} p<0.05$ multiple post hoc comparisons (Bonferroni correction).

Deletion of Kcnab2 resulted in more spikes in response to perithreshold stimulation (Fig. $7 A_{1}, A_{2}$ ). The group data (Fig. $7 B$ ) reveal that although both groups exhibited an increase in spiking in response to increased current injection (effect of increasing current: $\left.F_{(5,60)}=22.496, p=0.0001\right)$ neurons recorded in the lateral amygdala from Kcnab2 $2^{-/-}$mice exhibited significantly more spikes (genotype $\times$ spike interaction: $F_{(5,60)}=4.512, p=$ 0.03 ) with significant differences observed at current levels above $0.06 \mathrm{nA}$ (Bonferroni post hoc comparisons, $p<0.05$ ). Taken collectively, our whole-cell recordings demonstrate that deletion of Kcnab2 leads to a decrease in the sAHP as well as an aberrant increase in neuronal excitability.

\section{Discussion}

This study was motivated in large part by reports that the human ortholog of Kcnab2 (KCNAB2) is often deleted in patients diagnosed with monosomy 1 p36 deletion syndrome (Heilstedt et al., 2001). Learning disabilities, ranging from moderate deficits to severe mental retardation, are a common feature within this patient population (Heilstedt et al., 2003; D’Angelo et al., 2006). Therefore, we sought to determine whether deletion of Kcnab2 alone might disrupt cognitive function. We have found that deletion of Kcnab2 significantly disrupts amygdala-dependent associative learning in mice. Specifically, mice that lack Kcnab2 exhibit impairments in associative fear conditioning regardless of whether the CS is the conditioning context or a discrete cue such as an audible tone. The deficits in associative learning are not due to nonspecific impairments in shock reactivity, locomotor activity, auditory function, or altered emotionality. Kcnab2-null mice exhibited normal postshock freezing during training and were capable of exhibiting asymptotic levels of freezing that were indistinguishable from wild types. Auditory function in mice lack- 
ing Kcnab2 appeared to be normal, as measured by ABR. Similarly, locomotion and anxiety-like behavior in the open field and the light/dark box was not affected in the Kcnab2-null mice. The impairments in the processing of fear memories appear to be due to the loss of the Kv $\beta 2$ protein itself and not the AKR function of $\mathrm{Kv} \beta 2$, since mutant mice in which the catalytic AKR function is disrupted exhibit normal associative fear learning. To our knowledge, fear-associated learning has not been assessed in this patient population and although it is difficult to directly compare cognitive impairments observed in human patients with those observed in the Kcnab2-null mice, our data indicate that loss of $K C N A B 2$ in these patients would be expected to contribute to impairments in cognition. It should also be noted that we are not advancing the deficits in fear conditioning that we observed in Kcnab2-null mice as a putative model for the specific cognitive impairments associated with 1p36 deletion syndrome, but instead we are using the pavlovian fear conditioning paradigm as a way of assessing associative learning. It is also worth noting that deletion of Kcnab2 has been anecdotally reported to cause occasional seizures in some Kcnab2-null mice (McCormack et al., 2002; Connor et al., 2005), which mimics, to some extent, the seizure phenotype observed in some 1p36DS patients (Heilstedt et al., 2001), further supporting the idea that loss of KCNAB2 substantially contributes to the neurobehavioral complications observed in patients with 1p36DS. Although we did not observe any overt behavioral seizures in the mice that were used in these experiments, we cannot rule out the possibility that some mice may have experienced some sort of subtle seizure activity, which may have contributed to the observed deficits in their ability to encode new memories.

Deletion of Kcnab2 resulted in deficits in fear conditioning when either context or tone was used as the CS, suggesting that information encoding in the amygdala had been disrupted. Indeed, deletion of Kcnab2 produced a state of aberrant hyperexcitability within the lateral nucleus of the amygdala; projection neurons in the lateral amygdala in Kcnab2-null mice exhibited a significantly smaller postburst sAHP and significant reductions in spike accommodation. This alteration in intrinsic excitability does not appear to significantly impact long-term potentiation (LTP) in the lateral amygdala induced by high-frequency stimulation of cortical inputs to the lateral amygdala (data not shown). Although deletion of Kcnab2 does not appear to disrupt this form of LTP, it is possible that induction of LTP at the thalamic inputs or another form of LTP is disrupted in the Kcnab2-null mice. Our observations of a concomitant reduction in the sAHP and an increase in neuronal excitability are consistent with previous reports demonstrating that the sAHP regulates repetitive firing in the lateral amygdala (Faber and Sah, 2002, 2005). The observation that deletion of Kcnab2 predominately impacts the later component of the AHP is somewhat in contrast to results obtained in mice lacking Kcnab1, the gene that encodes the auxiliary potassium channel subunit $\mathrm{Kv} \beta 1$.1. In the CA1 region of the hippocampus, deletion of $\mathrm{Kv} \beta 1.1$ results in a decrease in the early component of the AHP (Giese et al., 1998; Murphy et al., 2004). It seems likely that the reduction in the early phase of the AHP in the $\mathrm{Kv} \beta 1.1$-null mice is related to the reduction in frequencydependent spike broadening, which is thought to result in a decrease in calcium influx during trains of action potentials (Giese et al., 1998; Murphy et al., 2004). However, our current results are consistent with previous experiments in the lateral amygdala demonstrating that spike broadening does not require inactivation of the repolarizing A-current or $\alpha$-dendrotoxin ( $\alpha$-DTX)sensitive channels (Faber and Sah, 2003a) and further suggest a novel relationship between $\mathrm{Kv} \beta 2$ and the generation of the sAHP. $\mathrm{Kv} \beta 2$ was first identified when it copurified with pore-forming subunits Kv1.1 and Kv1.2, receptors identified as targets for $\alpha$-DTX (Parcej and Dolly, 1989). Interestingly, it has been recently shown that blocking $\alpha$-DTX-sensitive currents in the rat amygdala leads to a modest change in the postburst afterhyperpolarization (Faber and Sah, 2004) (Table 1, columns 1 and 2) and a more pronounced significant change in the accommodation of these neurons (Faber and Sah, 2004), changes that we also identified in $\mathrm{Kv} \beta 2$-null mice here. Therefore, we hypothesize that the effects of the deletion of $\mathrm{Kv} \beta 2$ in the amygdala are mediated by a reduction of potassium current in a manner similar to the effect of application of $\alpha$-DTX.

In some regards, our finding that an aberrant increase in neuronal excitability is accompanied by impairments in associative learning might seem paradoxical. However, bidirectional plasticity of intrinsic excitability has been observed in the hippocampus, cortex, and cerebellum, and is thought by many to play an integral role in the encoding of new associative memories (Giese et al., 2001; Daoudal and Debanne, 2003; Zhang and Linden, 2003). Furthermore, experimental manipulations that artificially impose global hyperexcitability can disrupt the formation of longterm memories (Giese et al., 1998; Matthews and Disterhoft, 2009). Therefore, it would appear that there exists a nominal range of firing rates in which information is successfully encoded and deviations outside of this nominal range can manifest as cognitive impairments. In the lateral amygdala, it has been previously demonstrated that the firing rate of projection neurons in vivo is enhanced following pavlovian fear conditioning (Quirk et al., 1995, 1997; Goosens et al., 2003), and it has been suggested that the CS-evoked increases in firing rate may reflect the associative memory encoded in the lateral amygdala (Goosens et al., 2003). In addition to the overall increase in firing rate, it has been observed that fear conditioning produces an increase in short $(<10 \mathrm{~ms})$ interspike interval (ISI) events, suggesting an increase in burst firing (Quirk et al., 1995). Interestingly, the traininginduced increase in short ISI events was also accompanied by an increase in long ( 200-400 ms) ISI events, which may reflect the recruitment of feedforward inhibition (Quirk et al., 1995). In light of the well documented and well characterized AHP in these neurons, it would also seem plausible that the increase in long ISI events reflects the suppression of spiking imposed by the postburst AHP, which in these neurons peaks at $\sim 200-440 \mathrm{~ms}$ after the burst offset. Taken collectively, the data from these in vivo experiments suggest that rapid changes in firing rates play a critical role in encoding information during conditioning and that discrete bursts may also be required for the establishment of associative memories in the lateral amygdala. It is in this context that we advance the working hypothesis that the aberrant hyperexcitability and reduced AHP that we observed in the Kcnab2null mice disrupts the ability of the microcircuits within the lateral amygdala to encode associative representations of fearful memories.

\section{References}

Boettcher FA (2002) Presbyacusis and the auditory brainstem response. J Speech Lang Hear Res 45:1249-1261.

Brunzell DH, Coy AE, Ayres JJ, Meyer JS (2002) Prenatal cocaine effects on fear conditioning: exaggeration of sex-dependent context extinction. Neurotoxicol Teratol 24:161-172.

Connor JX, McCormack K, Pletsch A, Gaeta S, Ganetzky B, Chiu SY, Messing A (2005) Genetic modifiers of the Kv beta2-null phenotype in mice. Genes Brain Behav 4:77-88.

D’Angelo CS, Da Paz JA, Kim CA, Bertola DR, Castro CI, Varela MC, Koiff- 
mann CP (2006) Prader-Willi-like phenotype: investigation of 1p36 deletion in 41 patients with delayed psychomotor development, hypotonia, obesity and/or hyperphagia, learning disabilities and behavioral problems. Eur J Med Genet 49:451-460.

Daoudal G, Debanne D (2003) Long-term plasticity of intrinsic excitability: learning rules and mechanisms. Learn Mem 10:456-465.

Faber ES, Sah P (2002) Physiological role of calcium-activated potassium currents in the rat lateral amygdala. J Neurosci 22:1618-1628.

Faber ES, Sah P (2003a) $\mathrm{Ca}^{2+}$-activated $\mathrm{K}^{+}(\mathrm{BK})$ channel inactivation contributes to spike broadening during repetitive firing in the rat lateral amygdala. J Physiol 552:483-497.

Faber ES, Sah P (2003b) Calcium-activated potassium channels: multiple contributions to neuronal function. Neuroscientist 9:181-194.

Faber ES, Sah P (2004) Opioids inhibit lateral amygdala pyramidal neurons by enhancing a dendritic potassium current. J Neurosci 24:3031-3039.

Faber ES, Sah P (2005) Independent roles of calcium and voltage-dependent potassium currents in controlling spike frequency adaptation in lateral amygdala pyramidal neurons. Eur J Neurosci 22:1627-1635.

Gajecka M, Mackay KL, Shaffer LG (2007) Monosomy 1p36 deletion syndrome. Am J Med Genet C Semin Med Genet 145C:346-356.

Giese KP, Storm JF, Reuter D, Fedorov NB, Shao LR, Leicher T, Pongs O, Silva AJ (1998) Reduced $\mathrm{K}^{+}$channel inactivation, spike broadening, and after-hyperpolarization in Kvbeta1.1-deficient mice with impaired learning. Learn Mem 5:257-273.

Giese KP, Peters M, Vernon J (2001) Modulation of excitability as a learning and memory mechanism: a molecular genetic perspective. Physiol Behav 73:803-810.

Goosens KA, Hobin JA, Maren S (2003) Auditory-evoked spike firing in the lateral amygdala and Pavlovian fear conditioning: mnemonic code or fear bias? Neuron 40:1013-1022.

Heilstedt HA, Burgess DL, Anderson AE, Chedrawi A, Tharp B, Lee O, Kashork CD, Starkey DE, Wu YQ, Noebels JL, Shaffer LG, Shapira SK (2001) Loss of the potassium channel beta-subunit gene, KCNAB2, is associated with epilepsy in patients with 1 p36 deletion syndrome. Epilepsia 42:1103-1111.

Heilstedt HA, Ballif BC, Howard LA, Lewis RA, Stal S, Kashork CD, Bacino CA, Shapira SK, Shaffer LG (2003) Physical map of 1p36, placement of breakpoints in monosomy $1 \mathrm{p} 36$, and clinical characterization of the syndrome. Am J Hum Genet 72:1200-1212.

Kurosawa K, Kawame H, Okamoto N, Ochiai Y, Akatsuka A, Kobayashi M, Shimohira M, Mizuno S, Wada K, Fukushima Y, Kawawaki H, Yamamoto T, Masuno M, Imaizumi K, Kuroki Y (2005) Epilepsy and neurological findings in 11 individuals with 1p36 deletion syndrome. Brain Dev $27: 378-382$.

Matthews EA, Disterhoft JF (2009) Blocking the BK channel impedes acquisition of trace eyeblink conditioning. Learn Mem 16:106-109.

McCormack K, McCormack T, Tanouye M, Rudy B, Stühmer W (1995) Alternative splicing of the human Shaker $\mathrm{K}^{+}$channel beta 1 gene and functional expression of the beta 2 gene product. FEBS Lett 370:32-36.

McCormack K, Connor JX, Zhou L, Ho LL, Ganetzky B, Chiu SY, Messing A (2002) Genetic analysis of the mammalian $\mathrm{K}^{+}$channel $\beta$ subunit Kvbeta 2 (Kcnab2). J Biol Chem 277:13219-13228.
McCormack T, McCormack K (1994) Shaker $\mathrm{K}^{+}$channel beta subunits belong to an $\mathrm{NAD}(\mathrm{P}) \mathrm{H}$-dependent oxidoreductase superfamily. Cell 79:1133-1135.

McKinney BC, Murphy GG (2006) The L-Type voltage-gated calcium channel Cav1.3 mediates consolidation, but not extinction, of contextually conditioned fear in mice. Learn Mem 13:584-589.

McKinney BC, Schneider JS, Schafer GL, Lowing JL, Mohan S, Zhao MX, Heng MY, Albin RL, Seasholtz AF, Akil H, Murphy GG (2008a) Decreased locomotor activity in mice expressing tTA under control of the CaMKII alpha promoter. Genes Brain Behav 7:203-213.

McKinney BC, Chow CY, Meisler MH, Murphy GG (2008b) Exaggerated emotional behavior in mice heterozygous null for the sodium channel Scn8a $\left(\mathrm{Na}_{\mathrm{V}} 1.6\right)$. Genes Brain Behav 7:629-638.

Murphy GG, Fedorov NB, Giese KP, Ohno M, Friedman E, Chen R, Silva AJ (2004) Increased neuronal excitability, synaptic plasticity, and learning in aged Kvbeta1.1 knockout mice. Curr Biol 14:1907-1915.

Parcej DN, Dolly JO (1989) Dendrotoxin acceptor from bovine synaptic plasma membranes. Binding properties, purification and subunit composition of a putative constituent of certain voltage-activated $\mathrm{K}^{+}$channels. Biochem J 257:899-903.

Quirk GJ, Repa C, LeDoux JE (1995) Fear conditioning enhances shortlatency auditory responses of lateral amygdala neurons: parallel recordings in the freely behaving rat. Neuron 15:1029-1039.

Quirk GJ, Armony JL, LeDoux JE (1997) Fear conditioning enhances different temporal components of tone-evoked spike trains in auditory cortex and lateral amygdala. Neuron 19:613-624.

Sanders MJ, Kieffer BL, Fanselow MS (2005) Deletion of the mu opioid receptor results in impaired acquisition of Pavlovian context fear. Neurobiol Learn Mem 84:33-41.

Shi G, Nakahira K, Hammond S, Rhodes KJ, Schechter LE, Trimmer JS (1996) Beta subunits promote $\mathrm{K}^{+}$channel surface expression through effects early in biosynthesis. Neuron 16:843-852.

Tipparaju SM, Barski OA, Srivastava S, Bhatnagar A (2008) Catalytic mechanism and substrate specificity of the beta-subunit of the voltage-gated potassium channel. Biochemistry 47:8840-8854.

Torres YP, Morera FJ, Carvacho I, Latorre R (2007) A marriage of convenience: beta-subunits and voltage-dependent $\mathrm{K}^{+}$channels. J Biol Chem 282:24485-24489.

Washburn MS, Moises HC (1992) Muscarinic responses of rat basolateral amygdaloid neurons recorded in vitro. J Physiol 449:121-154.

Weng J, Cao Y, Moss N, Zhou M (2006) Modulation of voltage-dependent Shaker family potassium channels by an aldo-keto reductase. J Biol Chem 281:15194-15200.

Wu YQ, Heilstedt HA, Bedell JA, May KM, Starkey DE, McPherson JD, Shapira SK, Shaffer LG (1999) Molecular refinement of the 1p36 deletion syndrome reveals size diversity and a preponderance of maternally derived deletions. Hum Mol Genet 8:313-321.

Zhang W, Linden DJ (2003) The other side of the engram: experiencedriven changes in neuronal intrinsic excitability. Nat Rev Neurosci 4:885900. 